\title{
O nekim zadacima grafičkoga tipa iz vjerojatnosti i statistike
}

\author{
Luka Marohnić, Mandi Orlić Bachler, Bojan Kovačić
}

\section{Sažetak}

U radu se izlažu vlastita nastavna iskustva autora u primjeni nekih zadataka grafičkoga tipa u nastavi vjerojatnosti i statistike na stručnim studijima koji se izvode na Tehničkom veleučilištu u Zagrebu. Uz svaki zadatak navode se uobičajene poteškoće koje studenti imaju pri njegovu rješavanju te se ukazuje na moguće razloge tih poteškoća. Zaključno se predlaže kombiniranje ovakvih tipova zadataka sa standardnim zadacima radi uspješnijega postizanja planiranih ciljeva predmeta.

Ključni pojmovi: zadaci grafičkoga tipa, vjerojatnost i statistika, funkcija gustoće vjerojatnosti, funkcija razdiobe vjerojatnosti

\section{Uvod}

U nastavi vjerojatnosti i statistike na našim veleučilištima i samostalnim visokim školama većina zadataka koja se rješava na nastavi te zadaje na provjerama znanja pripada $\mathrm{u}$ tzv. tekstualne problemske zadatke, tj. zadatke u kojima su svi podaci potrebni za ispravno rješavanje zadani u tekstualnom obliku. Manji broj zadataka pripada u zadatke grafičkoga tipa, tj. u zadatke u kojima je većina podataka potrebna za ispravno rješavanje zadana grafički. O nekim zadacima takvoga tipa bit će riječi u ovom članku.

Ovaj je rad podržan od strane Hrvatske zaklade za znanost (HRZZ) u okviru projekta UIP-05-2017-9219. 
Radi jasnoće i kvalitetnijega razumijevanja izložene problematike, zadaci će biti izloženi u obliku riješenih primjera, pri čemu će uz svaki primjer biti navedeni komentari koji se odnose ponajprije na uočene poteškoće s kojima se susreću studenti prilikom rješavanja navedenoga zadatka. Ti su komentari zasnovani na vlastitim nastavnim iskustvima svih troje autora stečenima u nastavi predmeta Vjerojatnost i statistika na stručnim studijima elektrotehnike i graditeljstva Tehničkoga veleučilišta u Zagrebu.

\section{Primjer 1}

Na inicijalnom testu iz matematičkog predznanja potrebnog za praćenje nastave iz statistike bilo je moguće ostvariti od 0 do 5 bodova. $\mathrm{Na}$ sljedećem grafu (slika 1) prikazani su svi rezultati testa:

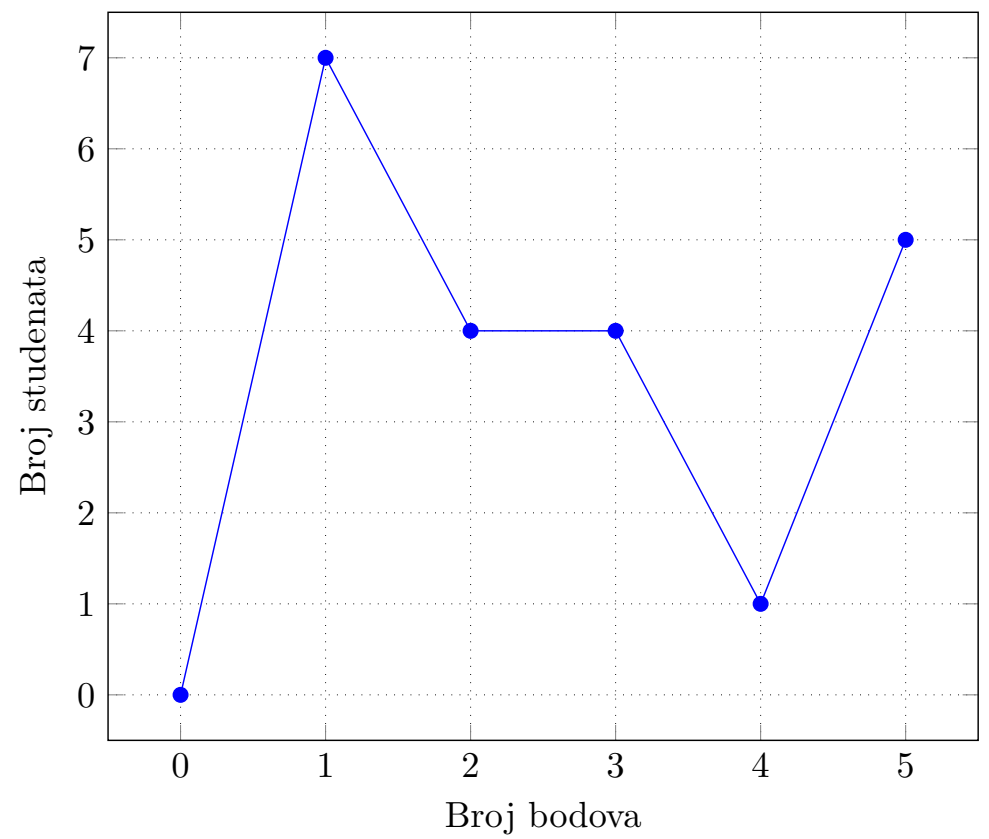

Slika 1. Rezultati inicijalnog testa iz matematike.

a) Prikažite tablicu apsolutnih frekvencija, relativnih frekvencija, relativnih frekvencija izraženih postocima, kumulativnih apsolutnih frekvencija i kumulativnih relativnih frekvencija izraženih postocima. 
b) Koliki je postotak studenata koji su dobili manje od 3 boda?

c) Odredite prvi i treći kvartil. Interpretirajte rezultat.

\subsection{Rješenje}

a) Podsjetimo se:

- apsolutna frekvencija $f_{i}$ modaliteta $y_{i}$ jednaka je ukupnom broju pojavljivanja dotičnog modaliteta u zadanom statističkom nizu,

- relativna frekvencija $r_{i}$ modaliteta $y_{i}$ definira se formulom ${ }^{1}$

$$
r_{i}=\frac{f_{i}}{n} \cdot 100[\%]
$$

- kumulativna apsolutna frekvencija „manje od" $f_{i}^{<}$modaliteta $y_{i}$ definira se formulom:

$$
f_{i}^{<}=\sum_{y_{j} \leq y_{i}} f_{j},
$$

- kumulativna relativna frekvencija „manje od" $f_{i}^{<}$modaliteta $y_{i}$ definira se formulom:

$$
r_{i}^{<}=\frac{f_{i}^{<}}{n} \cdot 100[\%] .
$$

Prema tome, tražena tablica frekvencija je:

\begin{tabular}{|c|c|c|c|c|c|}
\hline$y_{i}$ & $f_{i}$ & $\frac{f_{i}}{n}$ & $r_{i}$ & $f_{i}^{<}$ & $r_{i}^{<}$ \\
\hline \hline 0 & 0 & 0 & 0 & 0 & 0 \\
\hline 1 & 7 & 0.33 & $33 \%$ & 7 & $33 \%$ \\
\hline 2 & 4 & 0.19 & $19 \%$ & 9 & $52 \%$ \\
\hline 3 & 4 & 0.19 & $19 \%$ & 11 & $71 \%$ \\
\hline 4 & 1 & 0.05 & $5 \%$ & 16 & $76 \%$ \\
\hline 5 & 5 & 0.24 & $24 \%$ & 21 & $100 \%$ \\
\hline \hline Ukupno & 21 & 1 & $100 \%$ & - & - \\
\hline
\end{tabular}

b) Koristeći rezultat dobiven u a) podzadatku dobivamo da studenata koji su dobili manje od 3 boda ima $71 \%$.

c) Prvi i treći kvartil $Q_{1}$ i $Q_{3}$ mogu se procijeniti na više načina. Ovaj se primjer obrađuje u okviru nastave opisne statistike, pa će

\footnotetext{
${ }^{1}$ Budući da autori u radu sa studentima relativne frekvencije uvijek iskazuju $\mathrm{u}$ postocima, pripadne formule su ovdje tome prilagodene.
} 
za procjenu biti korištene sljedeće formule [6]:

$$
\begin{aligned}
& Q_{1}= \begin{cases}x_{\left\lceil\frac{n}{4}\right\rceil}, & \text { ako } n \text { nije djeljiv s } 4 ; \\
\frac{1}{2}\left(x_{\frac{n}{4}}+x_{\frac{n}{4}+1}\right), & \text { ako je } n \text { djeljiv s } 4 ;\end{cases} \\
& Q_{3}= \begin{cases}x_{\left\lceil\frac{3 n}{4}\right\rceil}, & \text { ako } n \text { nije djeljiv s } 4 ; \\
\frac{1}{2}\left(x_{\frac{3 n}{4}}+x_{\frac{3 n}{4}+1}\right), & \text { ako je } n \text { djeljiv s } 4 .\end{cases}
\end{aligned}
$$

Pritom pretpostavljamo da je $x_{1}, x_{2}, \ldots, x_{n}$ neopadajući niz dobiven uzlaznim sortiranjem zadanog statističkog niza s članovima u skupu modaliteta $\left\{y_{0}, \ldots, y_{5}\right\}$.

Kako je u zadatku $n=21$, tada dobivamo:

$$
Q_{1}=x_{\left\lceil\frac{n}{4}\right\rceil}=x_{6}=1 \quad \text { i } \quad Q_{3}=x_{\left\lceil\frac{3 n}{4}\right\rceil}=x_{16}=4 .
$$

Iz vrijednosti prvog kvartila zaključujemo da $75 \%$ studenata ima jedan bod ili više od jednog boda na testu. Iz vrijednosti trećeg kvartila zaključujemo da $25 \%$ studenata ima četiri ili više od četiri boda na testu.

\subsection{Komentari}

$\mathrm{U}$ a) podzadatku podatke s grafa studenti trebaju prikazati $u$ tabličnom obliku. Da bi to napravili, prvo moraju znati da je na osi ordinata, na kojoj je prikazan broj studenata, prikazana apsolutna frekvencija danih podataka. Nakon toga, primjenom odgovarajućih formula i definicija za relativnu frekvenciju, kumulativnu apsolutnu frekvenciju te kumulativnu relativnu frekvenciju, studenti mogu odrediti preostale tražene podatke. U pravilu, nakon što $\mathrm{u}$ tablicu unesu podatke o apsolutnoj frekvenciji ostvarenih bodova na testu, s određivanjem ostalih podataka nemaju previše problema i većina studenata točno zna odrediti sve preostale tražene vrijednosti.

Odgovor na b) podzadatak može se iščitati iz tablice frekvencija, i to iz podataka o kumulativnoj relativnoj frekvenciji izraženoj u postocima. U ovom je slučaju ključno znati definicije kumulativne apsolutne frekvencije „manje od" nekog modaliteta i kumulativne relativne frekvencije „manje od" nekog modaliteta. Iako studenti prepoznaju da odgovor na pitanje daje podatak o kumulativnoj relativnoj frekvenciji koji je izražen u postocima, značajan broj studenata dat će pogrešan odgovor na ovo pitanje te će odgovoriti da je postotak studenata koji su dobili manje od 3 boda jednak $52 \%$. Razlog tome je što pogrešno shvaćaju značenje sintagme „manje od" u definiciji kumulativne relativne frekvencije.

U c) podzadatku za određivanje prvog i trećeg kvartila prvo treba znati da se radi o uzorku u kojem imamo neparan broj elemenata, odnosno da u uzorku imamo neparan broj ispitanih studenata $(n=21)$. 
Nakon primjene odgovarajućih formula za prvi i treći kvartil, studenti se trebaju prisjetiti da funkcija $f: \mathbb{R} \rightarrow \mathbb{Z}$ definirana pravilom $f(n)=\left\lceil\frac{n}{4}\right\rceil$ svakom realnom broju $\frac{n}{4}$ pridružuje najmanji cijeli broj koji nije manji od $\frac{n}{4}$. Na ovom koraku jedan dio studenata najčešće radi sljedeću grešku i računa:

$$
x_{\left\lceil\frac{n}{4}\right\rceil}=x_{\lceil 5.25\rceil}=x_{5} .
$$

Naravno, točno je $x_{\left\lceil\frac{n}{4}\right\rceil}=x_{6}$. Međutim, jedan dio studenata $\mathrm{u}$ ovom koraku radi i sljedeću grešku i računa da je:

$$
x_{\left\lceil\frac{n}{4}\right\rceil}=x_{\lceil 5.25\rceil}=6 .
$$

Naime, vrijednost $x_{6}$ potrebno je iščitati iz tablice frekvencija i to iz podataka o kumulativnim apsolutnim frekvencijama i pripadajućim vrijednostima $x_{i}$.

\section{Primjer 2}

Biramo nasumice točku iz pravokutnika $\Omega=[-1,3] \times[0,2]$. Kolika je vjerojatnost da smo izabrali točku iz skupa S prikazanog na slici 2.

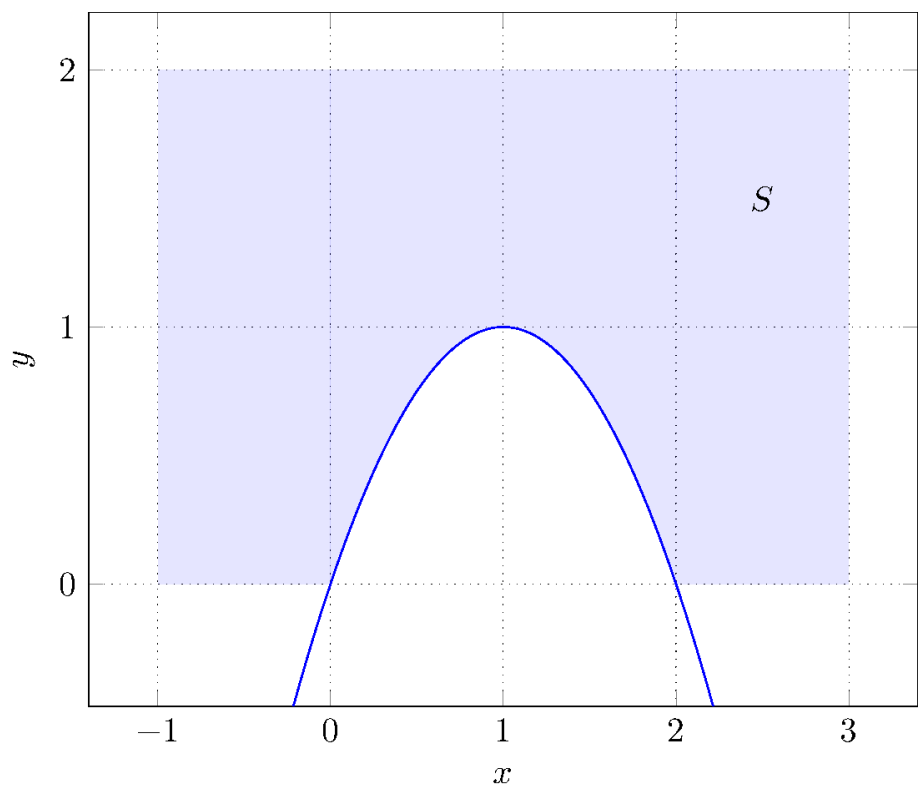

Slika 2. Kolika je vjerojatnost da smo izabrali točku iz skupa $S$ ? 


\subsection{Rješenje}

Ako su $\Omega$ i $A \subseteq \Omega$ ograničeni i izmjerljivi podskupovi skupa $\mathbb{R}^{n}$ za neki $n \in \mathbb{N}$, onda vjerojatnost događaja $A$ definiramo formulom:

$$
P(A)=\frac{m(A)}{m(\Omega)}
$$

gdje je $m$ Lebesgueova mjera na skupu $\mathbb{R}^{n}[5]$. Lebesgueova mjera $m$ svakom elementu familije izmjerljivih podskupova skupa $\mathbb{R}^{n}$ pridružuje nenegativan realan broj koji predstavlja njegov $n$-dimenzionalni volumen. Za $n=1$ mjera bilo kojega intervala jednaka je razlici gornje i donje granice toga intervala. Za $n=2$ mjera skupa jednaka je površini toga skupa. Za $n=3$ mjera skupa jednaka je volumenu toga skupa. Podskupovi od $\mathbb{R}^{n}$ za koje Lebesgueova mjera nije definirana su neizmjerljivi.

Funkciju definiranu formulom (1) nazivamo geometrijska vjerojatnost.

Kako se u našem zadatku radi o površini lika, tražena vjerojatnost računa se kao:

$$
P(S)=\frac{8-\int_{0}^{2}\left(-x^{2}+2 x\right) \mathrm{d} x}{8}=\frac{8-\frac{4}{3}}{8}=0.8
$$

\subsection{Komentari}

U rješavanju ovog zadatka ključno je prepoznati površinu lika $S$ koju treba izračunati kao razliku površine kvadrata $[-1,3] \times[0,2]$ i površine ispod luka krivulje na segmentu $[0,2]$.

Jednostavniji dio ovog zadatka je onaj u kojem treba odrediti površinu skupa $\Omega$ jer je ta površina jednaka površini pravoktnika $[-1,3] \times[0,2]$, odnosno ta površina iznosi $m(\Omega)=4 \cdot 2=8$.

Kod određivanja površine ispod luka krivulje na segmentu $[0,2]$ većina studenata prepoznat će da se radi o površini ispod luka parabole koja siječe os apscisa u točkama $(0,0)$ i $(2,0)$. Međutim, velik dio njih jednadžbu te parabole odredit će na sljedeći način:

$$
y=\left(x-x_{1}\right)\left(x-x_{2}\right)=(x-0)(x-2)=x^{2}-2 x .
$$

To je, naravno, pogrešno jer se jednadžba parabole traži u obliku $y=$ $a\left(x-x_{1}\right)\left(x-x_{2}\right)$. Ovdje je ključno prepoznati iz zadane slike da se radi o paraboli koja je okrenuta „prema dolje”, što znači da se radi o paraboli čiji je koeficijent uz $x^{2}$ negativan. Prema tome, točna jednadžba zadane parabole glasi: $y=-x^{2}+2 x$. Drugi problem s kojim se studenti susreću u ovom zadatku jest kako odrediti površinu ispod parabole na 
segmentu $[0,2]$. Naravno, ta površina računa se kao određeni integral čija je podintegralna funkcija upravo $-x^{2}+2 x$, a granice integrala su 0 i 2 :

$$
\int_{0}^{2}\left(-x^{2}+2 x\right) d x .
$$

Kako se ovdje radi o dva tablična integrala, uglavnom studenti nemaju problem s izračunom njegove vrijednosti.

Studenti koji su kao podintegralnu funkciju uvrstili $x^{2}-2 x$ dobit će da je $P(S)=1.17$ jer će vrijednost integrala iznositi $-\frac{4}{3}$. Oni studenti koji razmišljaju o dobivenim rezultatima i razumiju njihovo značenje, trebali bi prvo uvidjeti da površina ispod luka parabole ne može biti negativna i da dobivena vjerojatnost ne može biti veća od 1. Oba zaključka trebala bi ih navesti na to da su u zadatku napravili grešku.

\section{Primjer 3}

Slika 3 prikazuje ploču za pikado. Mali crveni kružić (engl. bulls eye) ima promjer od $1.25 \mathrm{~cm}$, a crveno-zeleni prstenovi su debljine $8 \mathrm{~mm}$ pri čemu se vanjski rub manjeg prstena nalazi na udaljenosti od $10 \mathrm{~cm}$, a vanjski rub većeg prstena na udaljenosti od $17 \mathrm{~cm}$ od središta ploče. $\mathrm{Na}$ slučajan smo način bacili pikado i pogodili unutar vanjskog ruba većeg prstena (dakle, u dio ploče koji donosi bodove). Izračunajte vjerojatnost da smo pogodili crveno obojani dio ploče.

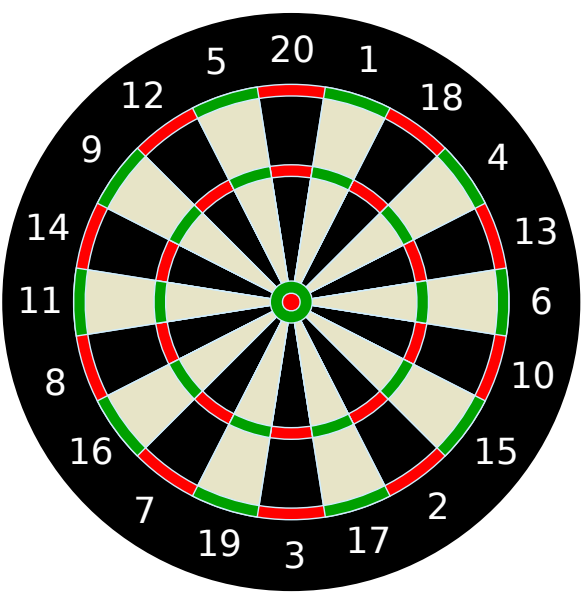

Slika 3. Ploča za pikado. 


\subsection{Rješenje}

Student u ovom zadatku treba primijeniti definiciju geometrijske vjerojatnosti gdje skup svih mogućih ishoda $\Omega$ odgovara krugu omeđenom vanjskim rubom većeg prstena, a skup svih povoljnih ishoda $A \subset \Omega \mathrm{cr}-$ veno obojanom dijelu ploče. Tražena vjerojatnost $P(A)$ je tada jednaka kvocijentu Lebesgueove mjere skupa $A$ i Lebesgueove mjere skupa $\Omega$.

Izračunati Lebesgueovu mjeru skupa $\Omega$ je jednostavno: ako $R$ označava polumjer vanjskog ruba većeg prstena, tada primjenom formule za površinu kruga dobivamo

$$
m(\Omega)=R^{2} \pi=17^{2} \pi \approx 907.92 \mathrm{~cm}^{2} .
$$

Izračunati Lebesgueovu mjeru skupa $A$ nešto je teže, ali ne uključuje nikakve dodatne formule. To je, međutim, glavni problem s kojim se student susreće u ovom zadatku. Dio studenata ipak će lako uočiti da je svaki od prstenova podijeljen u 20 jednakih dijelova od kojih je jedna polovica obojana crvenom a druga polovica zelenom bojom. Dakle, površina skupa $A$ jednaka je zbroju polovice površine većeg prstena, polovice površine manjeg prstena i površine crvenog kružića. Neka $d$, $r$ i $r_{0}$ označavaju debljinu prstenova, polumjer manjeg prstena i polumjer crvenog kružića (u centimetrima), redom. Površina kružnog prstena jednaka je razlici površina krugova omeđenih vanjskom, odnosno unutarnjom kružnicom, pa prema tome slijedi:

$$
\begin{aligned}
m(A) & =\overbrace{\frac{R^{2} \pi-(R-d)^{2} \pi}{2}}^{\text {veći prsten }}+\overbrace{\frac{r^{2} \pi-(r-d)^{2} \pi}{2}}^{\text {manji prsten }}+\underbrace{r_{0}^{2} \pi}_{\text {bulls eye }} \\
& =\left(R d+r d-d^{2}+r_{0}^{2}\right) \pi=\left(17 \cdot 0.8+10 \cdot 0.8-0.8^{2}+1.25^{2}\right) \pi \\
& \approx 70.757 \mathrm{~cm}^{2} .
\end{aligned}
$$

Napokon dobivamo

$$
P(A)=\frac{m(A)}{m(\Omega)} \approx 7.8 \% .
$$

\subsection{Komentari}

Većina studenata gotovo sigurno ne bi provela sređivanje algebarskog izraza kojim je zadana Lebesgueova mjera skupa $A$, već bi odmah krenuli s uvrštavanjem numeričkih podataka. Svakako treba inzistirati na maksimalnom sređivanju tog izraza budući da se radi o primjeni algebarskih formula poznatih još iz osnovne škole. Nadalje, moguće je da dio studenata izostavi crveni kružić (bulls eye) iz razmatranja mjere skupa 
svih povoljnih ishoda, stoga na to treba obratiti pozornost tijekom zajedničkog rješavanja zadatka.

\section{Primjer 4}

Neka je $X$ diskretna slučajna varijabla sa slikom $S=\{1,2,3,4,5,6,7\}$. Pripadna funkcija vjerojatnosti zadana je stupčastim grafikonom sa slike 4 (pretpostavljamo da svi stupci imaju širinu jednaku 1). Izračunajte $E(X)$ i $\sigma(X)$.

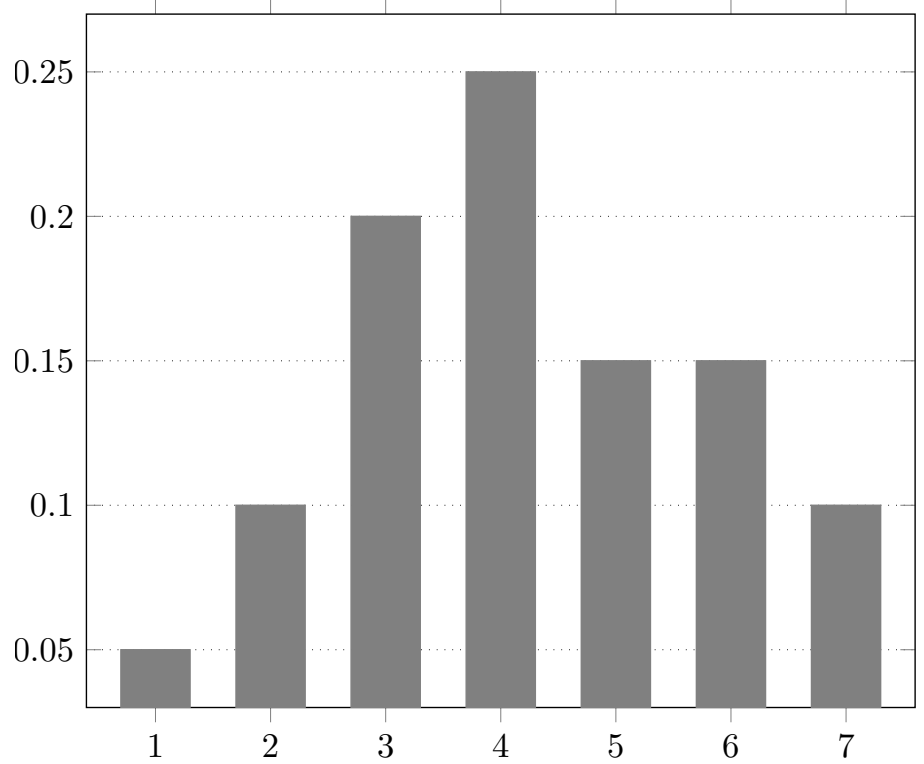

Slika 4. Funkcija vjerojatnosti diskretne slučajne varijeble $X$ sa slikom $S=\{1,2,3,4,5,6,7\}$.

\subsection{Rješenje}

U ovom primjeru važno je da student poznaje koncept diskretne slučajne varijable kako bi ispravno protumačio prikazanu sliku. Student treba pomoću zadanog grafikona elementima slike $S$ pridružiti odgovarajuće vjerojatnosti. Te su vjerojatnosti jednake površinama stupaca prikazanih u grafikonu. Budući da stupci imaju širinu jednaku 1, te površine jednake su visinama stupaca. 
Očitavanjem vjerojatnosti s grafikona dobivamo tablicu kojom je jednoznačno određena razdioba slučajne varijable $X[1,[3]$ :

$$
X \sim\left(\begin{array}{ccccccc}
1 & 2 & 3 & 4 & 5 & 6 & 7 \\
0.05 & 0.1 & 0.2 & 0.25 & 0.15 & 0.15 & 0.1
\end{array}\right)
$$

$\mathrm{u}$ čijem su gornjem retku navedeni elementi slike $s_{i}$, a u donjem retku pripadne vjerojatnosti $p_{i}$ da $X$ poprimi vrijednost $s_{i}$, za $i=1,2, \ldots, 7$.

Primjenom definicije matematičkog očekivanja za diskretne slučajne varijable [1, 3] dobivamo:

$$
E(X)=\sum_{i=1}^{7} s_{i} p_{i}=1 \cdot 0.05+2 \cdot 0.1+3 \cdot 0.2+4 \cdot 0.25+5 \cdot 0.15+6 \cdot 0.15+7 \cdot 0.1,
$$

što daje $E(X)=4.2$.

Da bismo izračunali standardnu devijaciju varijable $X$, najprije računamo varijancu od $X$ prema formuli $V(X)=E\left(X^{2}\right)-E(X)^{2}$ [1, 3]. Imamo

$$
X^{2} \sim\left(\begin{array}{ccccccc}
1^{2} & 2^{2} & 3^{2} & 4^{2} & 5^{2} & 6^{2} & 7^{2} \\
0.05 & 0.1 & 0.2 & 0.25 & 0.15 & 0.15 & 0.1
\end{array}\right)
$$

pa je

$$
\begin{aligned}
& E\left(X^{2}\right)=\sum_{i=1}^{7} s_{i}^{2} p_{i}= \\
& =1 \cdot 0.05+4 \cdot 0.1+9 \cdot 0.2+16 \cdot 0.25+25 \cdot 0.15+36 \cdot 0.15+49 \cdot 0.1 \\
& =20.3 .
\end{aligned}
$$

Sada računamo varijancu i standardnu devijaciju:

$$
\begin{aligned}
& V(X)=E\left(X^{2}\right)-E(X)^{2}=20.3-4.2^{2}=2.66 . \\
& \sigma(X)=\sqrt{V(X)} \approx 1.631 .
\end{aligned}
$$

\subsection{Komentari}

Formula $V(X)=E\left(X^{2}\right)-E(X)^{2}$ zbunjuje znatan broj studenata, od kojih dio pretpostavi da je $E\left(X^{2}\right)=E(X)^{2}$ i zaključi da je varijanca jednaka nuli. Naravno, nije tako: $E\left(X^{2}\right)$ je očekivanje varijable $X^{2}$, dok je $E(X)^{2}$ kvadrat očekivanja varijable $X$, što općenito nije isto. Stoga je dobro, barem prilikom prvog rješavanja zadatka ovog tipa, ispisati tablicu varijable $X^{2}$ te izračunati njezino očekivanje. 
Treba napomenuti da, s obzirom na iskustva s kolokvija i pismenih ispita, dio studenata previdi član $E(X)^{2}$ te računa samo zbroj u gornjoj formuli za $E\left(X^{2}\right)$. Također, neki studenti kvadriraju vjerojatnosti umjesto elemenata skupa $S$, čime u konačnici-nakon što su ispravno oduzeli član $E(X)^{2}$-dobivaju da je varijanca strogo negativan broj, što je nemoguće (studenti ovu pogrešku uoče tek kada moraju izračunati standardnu devijaciju kao drugi korijen iz varijance).

\section{Primjer 5}

Na slici 5 prikazan je graf funkcije gustoće vjerojatnosti eksponencijalne slučajne varijable $X$.

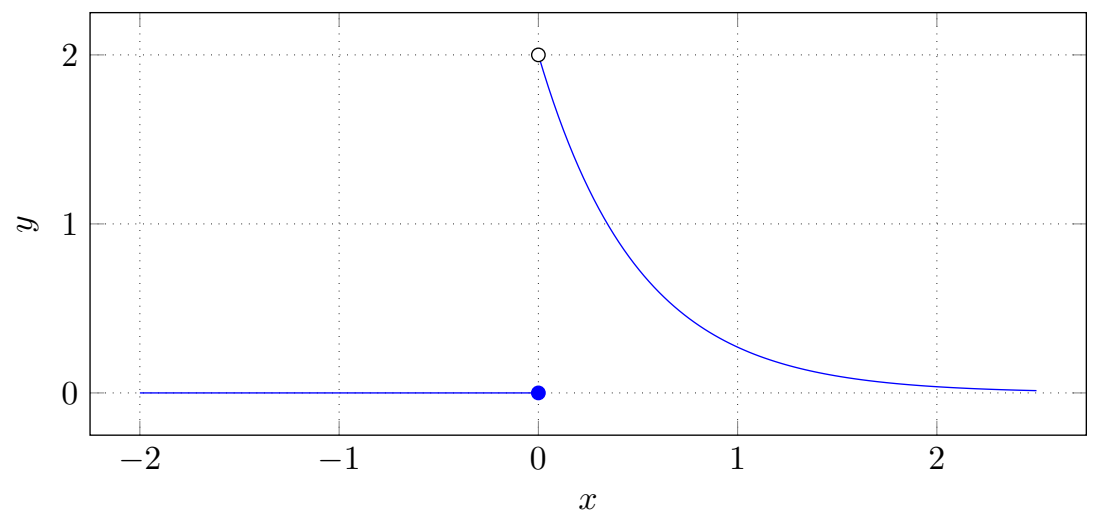

Slika 5. Funkcija gustoće vjerojatnosti eksponencijalne slučajne varijable X.

Odredite:

a) parametar pripadne eksponencijalne razdiobe;

b) pripadnu funkciju razdiobe vjerojatnosti (i nacrtajte njezin graf);

c) $P(0<X \leq 2)$.

\subsection{Rješenje}

Pretpostavimo da je $X \sim \operatorname{Exp}(a)$ za neki $a>0[3$. Podsjetimo da je funkcija gustoće $f$ te slučajne varijable tada dana pravilom [3]

$$
f(x)=\left\{\begin{array}{l}
a \cdot \mathrm{e}^{-a \cdot x}, \text { za } x>0, \\
0, \text { za } x \leq 0 .
\end{array}\right.
$$

a) Parametar $a$ jednak je limesu zdesna funkcije $f$ u točki $c=0$. Iz slike 5 se lako očita $\lim _{x \rightarrow 0+} f(x)=2$. Dakle, $a=2$, pa je $X \sim \operatorname{Exp}(2)$. 
b) Prema definiciji funkcije razdiobe vjerojatnosti $F$ [3] je

$$
F(x)=\int_{-\infty}^{x} f(t) \mathrm{d} t
$$

Ako je $x \leq 0$, onda je u tom slučaju očito $F(x)=0$.

Za $x>0$ dobivamo:

$$
F(x)=\int_{-\infty}^{x} f(t) \mathrm{d} t=\int_{0}^{x} f(t) \mathrm{d} t=\int_{0}^{x} 2 \mathrm{e}^{-2 t} \mathrm{~d} t=-\left.\mathrm{e}^{-2 t}\right|_{0} ^{x}=1-\mathrm{e}^{-2 x}
$$

Dakle,

$$
F(x)=\left\{\begin{array}{l}
1-\mathrm{e}^{-2 x}, \text { za } x>0 \\
0, \text { za } x \leq 0
\end{array}\right.
$$

Graf funkcije $F$ prikazan je na slici 6 .

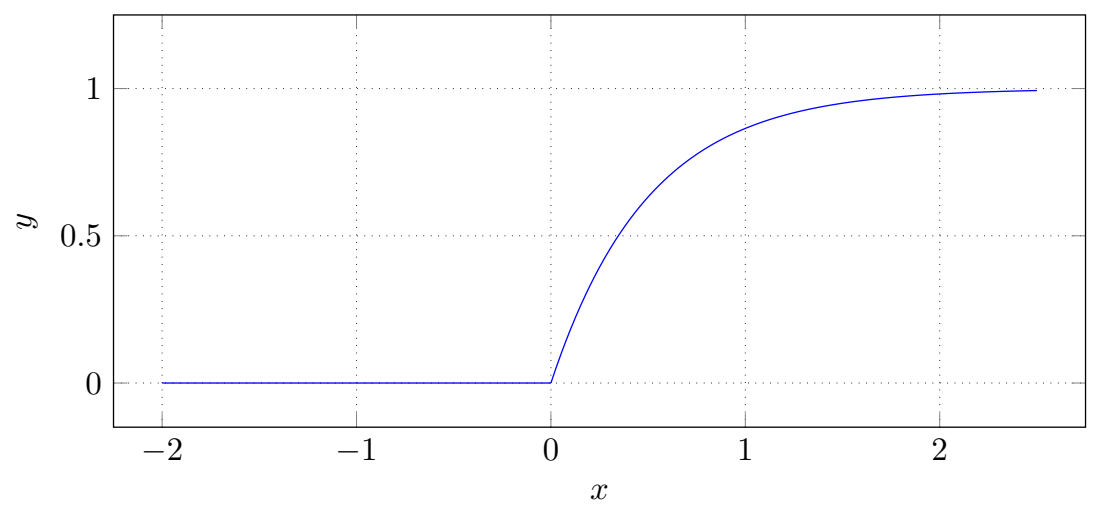

Slika 6. Funkcija razdiobe vjerojatnosti eksponencijalne slučajne varijable X.

c) Prema jednom od osnovnih svojstava funkcije razdiobe vjerojatnosti svake neprekidne slučajne varijable, vrijedi:

$$
P(a<X \leq b)=F(b)-F(a), \forall a, b \in \mathbb{R}: a<b .
$$

Koristeći rezultat b) podzadatka odmah dobivamo:

$$
P(0<X \leq 2)=F(2)-F(0)=1-\mathrm{e}^{-4} .
$$




\subsection{Komentari}

Prilikom rješavanja ovoga tipa zadatka ključno je prisjetiti se da za funkciju gustoće $f$ eksponencijalne slučajne varijable i pripadni parame$\operatorname{tar} a$ te varijable vrijedi jednakost $a=\lim _{x \rightarrow 0+} f(x)$. Iz slike 5 vidljivo je da funkcija $f$ nema limes u nuli, ali je definirana u nuli, te ima limese slijeva, odnosno zdesna u toj točki. Zbog toga student treba „povezati” koja od tih triju vrijednosti „ima veze” s parametrom $a$, čime će uspješno riješiti prvi podzadatak.

Ovdje vrijedi istaknuti da se, nakon proučavanja neprekidnih funkcija u kolegiju Matematika 1 na 1 . godini studija, studenti ponovno susreću s funkcijom koja je definirana, ali ne i neprekidna na $\mathbb{R}$. Ovakvi primjeri, kao i primjeri koji se obrađuju u okviru osnova harmonijske analize u kolegiju Matematika 2 na 1. godini studija, dodatno opravdavaju uvođenje pojma neprekidnosti u Matematici 1 koristeći Cauchyjevu definiciju toga pojma, a ne standardnu , $\varepsilon-\delta$ - definiciju”.

Prilikom rješavanja b) podzadatka studenti najčešće ne uočavaju da se nepravi integral iz definicije funkcije razdiobe vjerojatnosti zapravo svodi na „obični” određeni integral. Ova poteškoća proizlazi iz nedovoljnoga iskustva $\mathrm{u}$ određivanju nepravih integrala po dijelovima zadanih funkcija. Naime, u nastavnoj cjelini Nepravi integrali u okviru kolegija Matematika 2 standardno se rješavaju zadaci u kojima se traži određivanje nepravoga integrala integrabilne realne funkcije zadane jedinstvenim pravilom na cijeloj svojoj prirodnoj domeni (najčešće na skupu $\mathbb{R}$ ). Zbog toga je prilikom rješavanja ovoga podzadatka nužno detaljnije raspisati i komentirati postupak određivanja pravila funkcije $F$ te istovremeno ponoviti i osnovna svojstva određenih integrala (a posebno Newton-Leibnizovu formulu).

Nakon rješavanja ovoga podzadatka naglašava se da je funkcija $F$ neprekidna na $\mathbb{R}$, dok funkcija $f$ ima neuklonjivi prekid 1 . vrste (jedino) $\mathrm{u}$ točki $c=0$. Dio studenata intuitivno smatra da je derivacija svake neprekidne funkcije također neprekidna funkcija, pa sumnja $\mathrm{u}$ ispravnost dobivenoga rješenja. Ta sumnja proizlazi iz nedovoljnoga iskustva studenata $\mathrm{u}$ određivanju derivacije po dijelovima zadane funkcije jer se $\mathrm{u}$ kolegiju Matematika $1 \mathrm{u}$ pravilu određuju derivacije analitičkih funkcija zadanih jedinstvenim pravilom na svojoj prirodnoj domeni.

$\mathrm{U}$ c) podzadatku studentima je u pravilu „problematična” stroga nejednakost $X>0$. Naime, studenti (ispravno) povezuju određivanje tražene vjerojatnosti s Newton-Leibnizovom formulom, ali ih zbunjuje što napraviti ako je interval kojemu pripadaju vrijednosti varijable $X$ poluotvoren. Analogno kao u nastavi iz kolegija Matematika 2, tada je potrebno istaknuti da ,jedna točka grafa 'ne kvari' određeni integral", odnosno da se navedena jednakost može primijeniti i u slučaju poluotvo- 
renoga intervala.

Smatramo da ovaj zadatak izvrsno povezuje različita područja diferencijalnoga i integralnoga računa, te ilustrira na koje ih je načine moguće primijeniti i u gradivu koje prividno nema nikakve veze s tim dvama računima.

\section{Primjer 6}

Na slici 7 prikazan je graf funkcije gustoće normalne slučajne varijable $Y$. Površina osjenčanoga lika iznosi (približno) 0.19146 kv. jed.

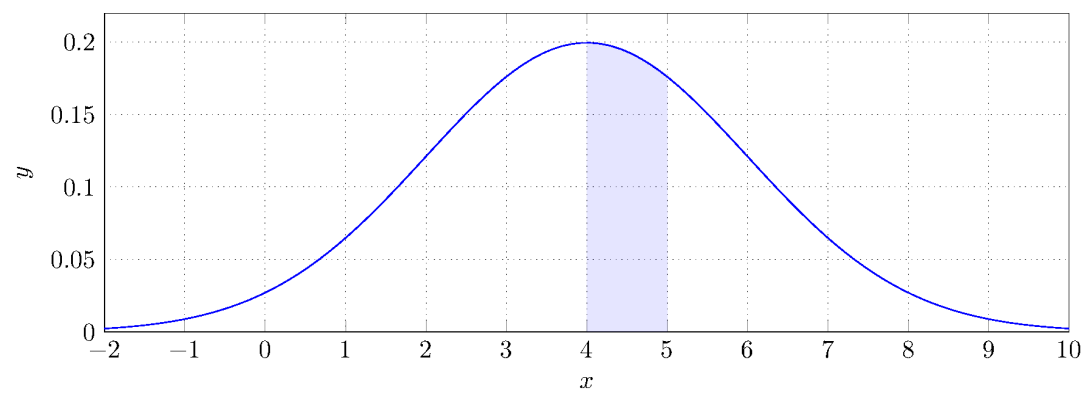

Slika 7. Funkcija gustoće normalne slučajne varijable $Y$.

Odredite:

a) parametre pripadne normalne razdiobe ako je poznato da su oni prirodni brojevi;

b) $P(Y>6)$.

\subsection{Rješenje}

Pretpostavimo da je $Y \sim N\left(\mu, \sigma^{2}\right)$ za neke $\mu, \sigma \in \mathbb{N}$ [7]. Označimo s $f$ (zadanu) funkciju gustoće, s $F$ pripadnu funkciju razdiobe vjerojatnosti varijable $Y$, a s $F^{*}$ funkciju razdiobe vjerojatnosti standardne (jedinične) normalne slučajne varijable.

a) Znamo da funkcija $f$ poprima svoju najveću vrijednost (globalni maksimum) za $x=\mu$. Iz slike se vidi da se ta vrijednost poprima za $x=4$. Dakle, $\mu=4$. 
Nadalje, površina osjenčanoga lika jednaka je:

$$
\begin{aligned}
P & =F(5)-F(4)=F^{*}\left(\frac{5-4}{\sigma}\right)-F^{*}\left(\frac{4-4}{\sigma}\right) \\
& =F^{*}\left(\frac{1}{\sigma}\right)-F^{*}(0)=F^{*}\left(\frac{1}{\sigma}\right)-0.5 .
\end{aligned}
$$

Prema podacima iz zadatka, ta površina mora biti jednaka 0.19146 kv. jed., pa dalje slijedi:

$$
F^{*}\left(\frac{1}{\sigma}\right)=0.69146 \Leftrightarrow \frac{1}{\sigma}=0.5 \Leftrightarrow \sigma=2 .
$$

Dakle, $Y \sim N\left(4,2^{2}\right)$.

b) Koristeći tablicu vrijednosti funkcije razdiobe vjerojatnosti standardne normalne slučajne varijable, dobivamo:

$$
\begin{aligned}
P(Y>6) & =1-P(Y \leq 6)=1-F(6)=1-F^{*}\left(\frac{6-4}{2}\right)=1-F^{*}(1) \\
& \approx 1-0.84135=0.15865 .
\end{aligned}
$$

\subsection{Komentari}

Ovaj zadatak nije u potpunosti grafičkoga tipa jer su za njegovo ispravno rješavanje potrebni dodatni ne-grafički podaci (mjerni broj površine i uvjet da su oba parametra razdiobe prirodni brojevi). Međutim, relativnu većinu ostalih podataka potrebnih za ispravno rješavanje je ipak potrebno „očitati” sa slike 7. pa smatramo da se zbog toga zadatak može svrstati u zadatke grafičkoga tipa.

Prva poteškoća koju studenti imaju pri rješavanju ovoga zadatka je zaključivanje je li očekivanje najveća vrijednost zadane funkcije gustoće ili vrijednost nezavisne varijable za koju se postiže ta najveća vrijednost. U tom je smislu zadatak namjerno postavljen tako da je na slici 7 istaknuta točka globalnoga maksimuma funkcije gustoće. Pritom je vrijednost toga maksimuma ,vrlo blizu” 0.2 tako da student (neispravno) u razmatranje uzme i tu vrijednost. (Napomenimo da je egzaktna najveća vrijednost funkcije gustoće $f_{\max }=\frac{1}{2 \cdot \sqrt{2 \cdot \pi}}$, što približno iznosi 0.19947.)

Druga poteškoća studenata odnosi se na povezivanje mjernoga broja površine osjenčanoga lika s vrijednostima funkcije razdiobe vjerojatnosti. U kolegiju Matematika 2 studenti su mjerni broj površine (ispravno) povezivali s određenim integralom funkcije čiji graf određuje jednu stranicu krivocrtnoga trapeza. Tako i u ovom slučaju dio studenata zaključuje 
da vrijedi jednakost:

$$
\int_{5}^{6} f(x) \mathrm{d} x=0.19146 \Leftrightarrow \int_{5}^{6} \frac{1}{\sigma \cdot \sqrt{2 \cdot \pi}} \cdot \mathrm{e}^{\frac{-(x-4)^{2}}{2 \cdot \sigma^{2}}} \mathrm{~d} x=0.19146 .
$$

Na ovom mjestu studenti zastanu jer podintegralna funkcija nije elementarno integrabilna, pa odredeni integral na lijevoj strani jednakosti nije moguće elementarno izračunati koristeći uobičajene postupke poznate iz osnova integralnoga računa. Tada studente treba podsjetiti na osnovnu vezu funkcije razdiobe vjerojatnosti $F$ i funkcije gustoće vjerojatnosti $f$ neprekidne slučajne varijable, tj. na relaciju $F^{\prime}=f$. Također, treba podsjetiti i na Newton-Leibnizovu formulu u kojoj se-u ovom slučajufunkcija razdiobe vjerojatnosti $F$ pojavljuje kao standardna antiderivacija funkcije gustoće vjerojatnosti $f$.

Standardizaciju promatrane normalne slučajne varijable većina studenata napravi „rutinski”, tj. bez prethodnoga definiranja nove slučajne varijable $Z=\frac{X-\mu}{\sigma}$ i zaključivanja da je $Z \sim N(0,1)$. Postupak standardizacije normalne slučajne varijable i njegova svrha detaljnije se objašnjavaju na predavanjima, pa ga zato studenti primjenjuju manje-više „mehanički” bez razmišljanja o čemu se tu zapravo radi. Ovaj problem postaje najočitiji kad studente upitamo za objašnjenje koraka $F(5)-$ $F(4)=F^{*}\left(\frac{5-4}{\sigma}\right)-F^{*}\left(\frac{4-4}{\sigma}\right)$. U grubim crtama, njihov se odgovor praktički svodi na izjavu: „Pa, Vi ste nam tako rekli...”, što ukazuje na opravdanu potrebu da se na „konkretnim” zadacima višekratno ukazuje na smisao i značaj postupka standardizacije.

Posljednja poteškoća koja se javlja u rješavanju ovoga tipa zadatka odnosi se na određivanje vjerojatnosti $P(Y>6)$. Na temelju iskustava stečenih rješavanjem zadataka koji se odnose na diskretne slučajne varijable, dio studenata (netočno) zaključuje:

$$
P(Y>6)=P(Y \geq 7)
$$

pa rješavanje zadatka nastavlja koristeći vjerojatnost $P(Y \geq 7)$. Na temelju istih iskustava dio studenata zbunjuje (točna) jednakost

$$
P(Y>6)=P(Y \geq 6)
$$

koja se u pravilu spomene jer želimo naglasiti da se opisani postupak rješavanja provodi neovisno o tome vrijedi li stroga ili blaža nejednakost. Zbog toga je i u ovom slučaju potrebno podsjetiti studente da „jedna točka grafa ne kvari određeni integral". 


\section{Zaključak}

Pri izboru zadataka koji se rješavaju u okviru gradiva iz vjerojatnosti i statistike na našim visokoobrazovnim ustanovama nužno je voditi računa o postavljenim ciljevima kolegija i ishodima učenja. Na stručnim studijima elektrotehnike i graditeljstva Tehničkoga veleučilišta u Zagrebu cilj kolegija Vjerojatnost $i$ statistika jest upoznavanje s osnovama vjerojatnosti i osnovnim statističkim metodama i postupcima, dok u standardne ishode učenja pripadaju zadatci kao što je npr. izračunati osnovne statističke pokazatelje numeričkoga niza, izračunati vjerojatnost događaja u osnovnim izmjerivim podskupovima ravnine i prostora, izračunati osnovne statističke pokazatelje diskretnih i neprekidnih slučajnih varijabli i dr.

Izborom zadataka u ovom članku nastojali smo pokazati da se cilj kolegija i ishodi učenja mogu postići i rješavanjem zadataka grafičkoga tipa. Uvjereni smo da se takvim tipom zadataka može staviti veći naglasak na razumijevanje definicija i formula potrebnih za njihovo rješavanje. To razumijevanje posebno dolazi do izražaja pri povezivanju gradiva vjerojatnosti i statistike s osnovama diferencijalnoga i integralnoga računa. Iz uočenih poteškoća koje imaju studenti prilikom rješavanja zadataka jasno se vidi sav značaj učenja gradiva s razumijevanjem, a ne „učenja za ispit" čemu je sklona većina studenata.

Kao optimalnu strategiju izbora zadataka u svrhu postizanja cilja kolegija i ishoda učenja predlažemo kombiniranje „standardnih” (tekstualnih) problemskih zadataka i zadataka grafičkoga tipa. Takva strategija izvrsno se ocrtava npr. u obradi gradiva geometrijske vjerojatnosti. Primjeri primjene geometrijske vjerojatnosti u slučaju kad je vjerojatnosni prostor ravninski lik u ravnini mogu biti primjeri 2 i 3 iz ovoga članka, dok primjeri primjene iste vjerojatnosti u slučaju kad je vjerojatnosni prostor neki „,klasičan” podskup skupa $\mathbb{R}$ ili skupa $\mathbb{R}^{3}$ (standardnoga euklidskoga trodimenzionalnoga prostora) mogu biti tekstualni problemski zadaci. Smatramo da će takvom kombinacijom različitih tipova zadataka - po mogućnosti, što više povezanih sa „svakodnevnim životom”, tj. realnim tehničkim i poslovnim procesima - gradivo kolegija biti zanimljivije većini studenata i da će se time vrlo uspješno „srušiti” standardni stereotip o vjerojatnosti i statistici kao skupu definicija, formula i postupaka koji su jasni i zanimljivi samo statističarima.

\section{Literatura}

[1] M. Benšić, N. Šuvak, Uvod u vjerojatnost $i$ statistiku, Odjel za matematiku Sveučilišta u Osijeku, Osijek, 2013. 
[2] N. Elezović, Slučajne varijable, Element, Zagreb, 2007.

[3] N. Elezović, Vjerojatnost i statistika, Element, Zagreb, 2018.

[4] M. Ilijašević, Ž. Pauše, Riješeni primjeri $i$ zadaci iz vjerojatnosti $i$ statistike, "Zagreb" poduzeće za grafičku djelatnost, Zagreb, 1990.

[5] S. Mardešić, Matematička analiza u n-dimenzionalnom realnom prostoru, drugi dio: Integral i mjera, Školska knjiga, Zagreb, 1989.

[6] M. Papić, Primijenjena statistika u MS Excelu za ekonomiste, znanstvenike $i$ neznalice, Naklada Zoro, 2014.

[7] S. Suljagić, Vjerojatnost $i$ statistika, skripta, 2005.

Luka Marohnić

Tehničko veleučilište u Zagrebu, Katedra za matematiku, 10000 Zagreb, Konavoska 2, Hrvatska

E-mail adresa: luka.marohnic@tvz.hr

Mandi Orlić Bachler

Tehničko veleučilište u Zagrebu, Katedra za matematiku, 10000 Zagreb, Av. V. Holjevca 15, Hrvatska

E-mail adresa: mandi.orlic@tvz.hr

Bojan Kovačić

Tehničko veleučilište u Zagrebu, Katedra za matematiku, 10000 Zagreb, Konavoska 2, Hrvatska

E-mail adresa: bojan.kovacic@tvz.hr 